\title{
Hydrochemical zoning of valley peatlands as a result of water supply conditions: examples from Poland
}

\author{
Maciej Ziułkiewicz, Anna Fortuniak \\ University of Łódź, Faculty of Geographical Sciences, Laboratory of Geology; ul. Narutowicza 88, 90-139 Łódź, Poland; \\ e-mail:macziul@uni.lodz.pl,anna.fortuniak@geo.uni.lodz.pl
} (c) 2016 Authors. This is an open access publication, which can be used, distributed and reproduced in any medium according
to the Creative Commons CC-BY 4.0 License requiring that the original work has been properly cited.

Received: 30 November 2015; accepted: 19 April 2016

\begin{abstract}
The chemical composition of water from two peatlands was investigated. Both peatlands, which are nature reserves, are located in central Poland in the Widawka and Rawka River valleys. The study concerned groundwaters, peat waters from different depths, and waters from draining ditches. The research permitted determination of the hydrochemical zoning of the peatlands resulting from the complex character of the water supply. The hydrochemical interpretation of surface waters outflowing alongside the ditches, in terms of their similarity to particular zones, provides an insight into the water-feeding structure of the peatlands. In the evaluation, hydrochemical indicators were applied, which have been used in hydrogeological studies. They are based on equivalent concentrations of the major ions: sodium, calcium, chlorides, and sulphates, selected from other hydrochemical elements by means of principal component analysis (PCA), conducted individually for each peatland. The analyses showed a high contribution of unconfined and confined groundwaters to the water supply, with clearly distinguishable zones, in terms of their transit through the structures of the peatlands.
\end{abstract}

Keywords: valley peatland, hydrochemical zoning, hydrochemical indicators

\section{INTRODUCTION}

Peatlands located in river valleys represent complex water feeding patterns. They are permanently supplied with groundwaters, periodically or irregularly with fluvial flood waters, and relatively regularly with precipitation waters. Depending on the local hydrological conditions, peat-forming processes in river valleys take various courses: from the development of full peat cover, through partial cover, to complete lack of peatlands (Żurek 1990). Irrespective of the degree of peat cover, however, the location of a peatland in a valley bottom has implications for the water budget. In simple terms, in a cross-section of the valley bottom, the further they are from the river channel, the lower the contribution of flood waters to groundwater supply. With regard to rainfall, at the boundary of the valley, peatlands are primarily dependent on the groundwater supply, except in particularly extreme flood events. Therefore, valley peatland is dependent on the transition landscape, i.e. on the adjacent valley slope. In addition, because of its location at the foot of the slope, the peatland forms a part of the eluvial accumulation zone of the valley bottom. Groundwater inflow and outflow transform valley peatland into a rich fen. Evolution towards a transitional and raised bog develops, and gradually increases such autonomy with respect to groundwaters, when the transformation of the bottom peat layers leads to self-sealing of a peat water body. The peat layer loses hydraulic contact with 
groundwaters, and then, meteoric waters become the main element of water feed (Tahvanainen \& Tuomaala 2003). Such separation of the biogeochemical and bedrock environments has an ecological impact, among others on the distribution of particular plant assemblages within peatlands.

The possibilities of direct observation of water supply to peatlands are very limited, particularly in the case of groundwater supply. Therefore, it is difficult to determine the hydrological role of peatlands in catchments (Ilnicki 2002). Knowledge on the hydrogeological structure of the adjacent areas, i.e. number of aquifers, their efficiency, and the structure of underground supply, is usually scarce (Falkowski \& Złotoszewska-Niedziałek 2008). River valleys are among the most varied and complicated hydrogeological units, reflecting the diversity of their hydrogeochemical conditions (Macioszczyk 1988). Consequently, the waters flowing out of peatlands are also the only apparent representation of the outputs elements of the mineral component balance in a peatland, leading to the determination of the hydrochemical role of peatlands in the atmospheric input and surface water runoff (Kruk 2000, Kruk \& Podbielska 2005). Hydrochemical observations of outflow with determined composition and parameters of ground and precipitation waters permit the determination of the hydrological feeding structure, with an assumption of no floodwaters.
The objective of the research is to provide a method of interpretation of a peatland hydrological feeding structure based on the outflow hydrochemistry.

This study adopts three steps:

1) identification of primary components, which cause hydrochemical diversity within two peatlands in relation to water supply from different environments,

2) assessment of the water mixing scale inside two peatlands based on indicated components,

3) assessment of the outflow hydrochemistry in the scope of genetic hydrochemical zoning of the peatlands.

\section{MATERIAL AND METHODS}

\section{Study area}

The study was conducted in two valley peatlands located in Central Poland in the valleys of the Rawka and Widawka rivers (Fig. 1). Both peatlands fill old ox-bows and form extremely multiradial landforms separated from the present flood zone in the valley by morphological barriers. Kopanicha has been under legal protection since 1980 and Korzeń since 1998. The peatlands are unique sites in Central Poland, relatively weakly transformed by peat mining, agricultural impact or land improvement (Forysiak et al. 2012). Further details of the studied peatlands are presented in Table 1.

Table 1

Basic characteristics of the studied valley peatlands

\begin{tabular}{|c|c|c|}
\hline Feature & Korzeń peatland (KR) & Kopanicha peatland (KA) \\
\hline Geographical coordinates & 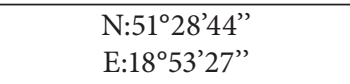 & $\begin{array}{l}\mathrm{N}: 52^{\circ} 00^{\prime} 06^{\prime \prime} \\
\mathrm{E}: 20^{\circ} 12^{\prime} 02^{\prime \prime}\end{array}$ \\
\hline River name & Widawka & Rawka \\
\hline Physical-geographical region & Sieradzka Basin & Łowicko-Błońska Plain \\
\hline Area & 9 ha & 70 ha \\
\hline Max. peat thickness & $2.0 \mathrm{~m}$ & $3.8 \mathrm{~m}$ \\
\hline $\begin{array}{l}\text { Dominant plant assemblage } \\
\text { (Forysiak et al. 2011) }\end{array}$ & $\begin{array}{l}\text { common cottongrass, } \\
\text { Sphagnum fallax } \\
\text { Eriophoro angustifolii- } \\
\text { Sphagnetum recurvi }\end{array}$ & $\begin{array}{c}\text { currant and sphagnum alder } \\
\text { forest, marshy coniferous forest } \\
\text { Ribeso nigri-Alnetum, } \\
\text { Sphagno squarrosi-Alnetum, } \\
\text { Vaccinio uliginosi-Pinetum }\end{array}$ \\
\hline Type & transitional bog/fen & fen \\
\hline $\begin{array}{l}\text { Degree of naturalness } \\
\text { (Banaś\&Gos 2004) }\end{array}$ & moderate & moderate \\
\hline $\begin{array}{l}\text { Type of hydrological feeding } \\
\text { (Dembek\&Oświt 1992) }\end{array}$ & $\begin{array}{l}\text { soligenic - supply by } \\
\text { unconfined groundwaters }\end{array}$ & $\begin{array}{l}\text { soligenic - supply by unconfined and } \\
\text { probably confined }{ }^{\star} \text { groundwaters }\end{array}$ \\
\hline
\end{tabular}

* According to Żurek (1990) and Kobojek (2009), this is suggested by the analogy to other nearby parts of the Rawka River valley. 


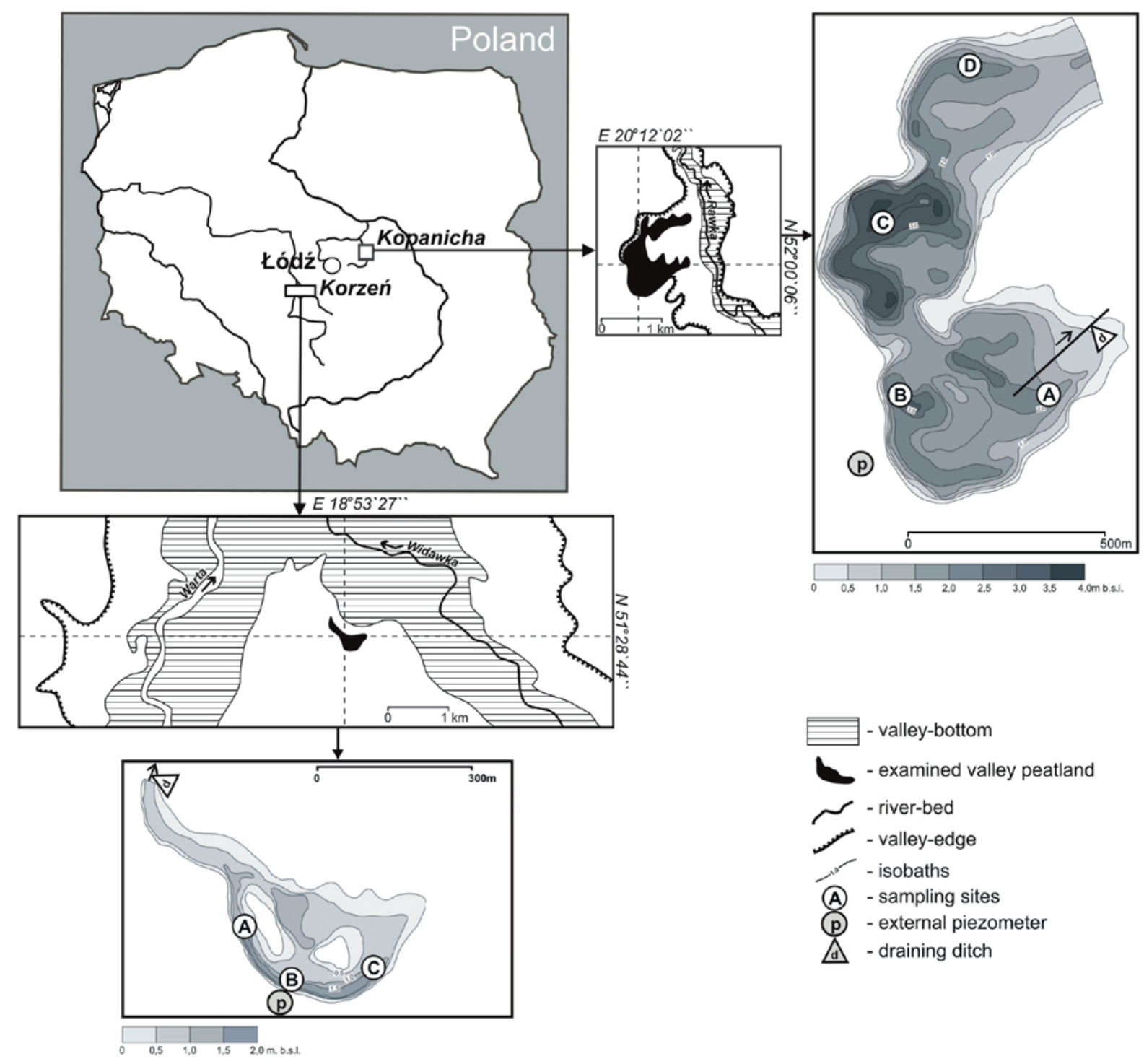

Fig. 1. Location of the studied sites. Geomorphological maps of the valleys according to Brzeziński (1998) and Krzemiński \& Bezkowska (1987); bathymetric study according to Forysiak (2012)

The Korzen peatland (KR) is formed of organogenic sediments, which are underlain by silty gyttja. The middle and upper parts of deposits are composed of transitional sphagnum and thicket peats. From a depth of $0.55 \mathrm{~m}$ to $0.8 \mathrm{~m}$, the peat presents a low degree of decomposition $\left(\mathrm{H}_{2}\right)$. Deeper, from $0.8 \mathrm{~m}$, the degree of decomposition substantially increases to $\mathrm{H}_{7}$. Deeper than $1.1 \mathrm{~m}$, it decreases to $\mathrm{H}_{4}$ (Forysiak 2012).

The Kopanicha peatland (KA) is composed of a layer of fluvial aggradate muds at the bottom, covered with a layer of alder peat $(1.2 \mathrm{~m})$, and higher sedge peat $(0.6 \mathrm{~m})$, moss peat $(0.4 \mathrm{~m})$ and moss-sedge peat at the surface $(0.4 \mathrm{~m})$. The surface of the peatland is covered by a layer of humus with a thickness of $0.3 \mathrm{~m}$. The degree of decomposition of the peat varies from $\mathrm{H}_{6}$ at the surface and bottom to $\mathrm{H}_{3}$ between depths of 0.5 and $0.8 \mathrm{~m}$ (Forysiak 2012).

The Korzeń peatland is fed by unconfined groundwaters inflowing through medium-grained and fine sands of the upper terrace, covering boulder clay from the Warta Glaciation (Skąpski et al. 2000). The Kopanicha peatland is fed by unconfined groundwaters directly through the undercut edge of the plateau. The horizon of 
clays supporting unconfined waters is probably also dissected. In addition, confined groundwater inflow into the peatland from under the horizon (Żurek 1990, Kobojek 2009).

\section{Sampling and laboratory analysis}

The preparatory works involved sounding of the peat thickness and determination of the ox-bow bottom morphology. The results allowed us to verify the size and shape of the peatland and to develop bathymetric plans (Fig. 1). This, in turn, allowed us to locate the measurement points. The deepest locations were selected (Fig. 1).

Groundwater levels in the peat were measured by means of piezometer nests. Four nests were used of three piezometers for KA and three nests of two piezometers for KR (Fig. 1).
The piezometers were made of PVC pipes with a $5.0 \mathrm{~cm}$ internal diameter. The deepest piezometer reached the bottom of the peatland, in the zone where the mineral and organic sediments abut one another (Figs 2,3) and in places where groundwaters could effectively interfuse to peatland. The shortest piezometer measured near-surface waters in peat layer at a depth of $40-50 \mathrm{~cm}$, affected by precipitation (Mitchell \& Branfireun 2005). This is also the zone where, according to Wieder \& Lang (1986), primary horizontal water flows occur in the peatland. Because of the thickness of the peat, a third piezometer in each of the nests was installed in KA, reaching the middle part of the profile, on the assumption that it was located at a considerable distance from the surface and bottom sediments (180 $\mathrm{cm}$ below ground level).

A
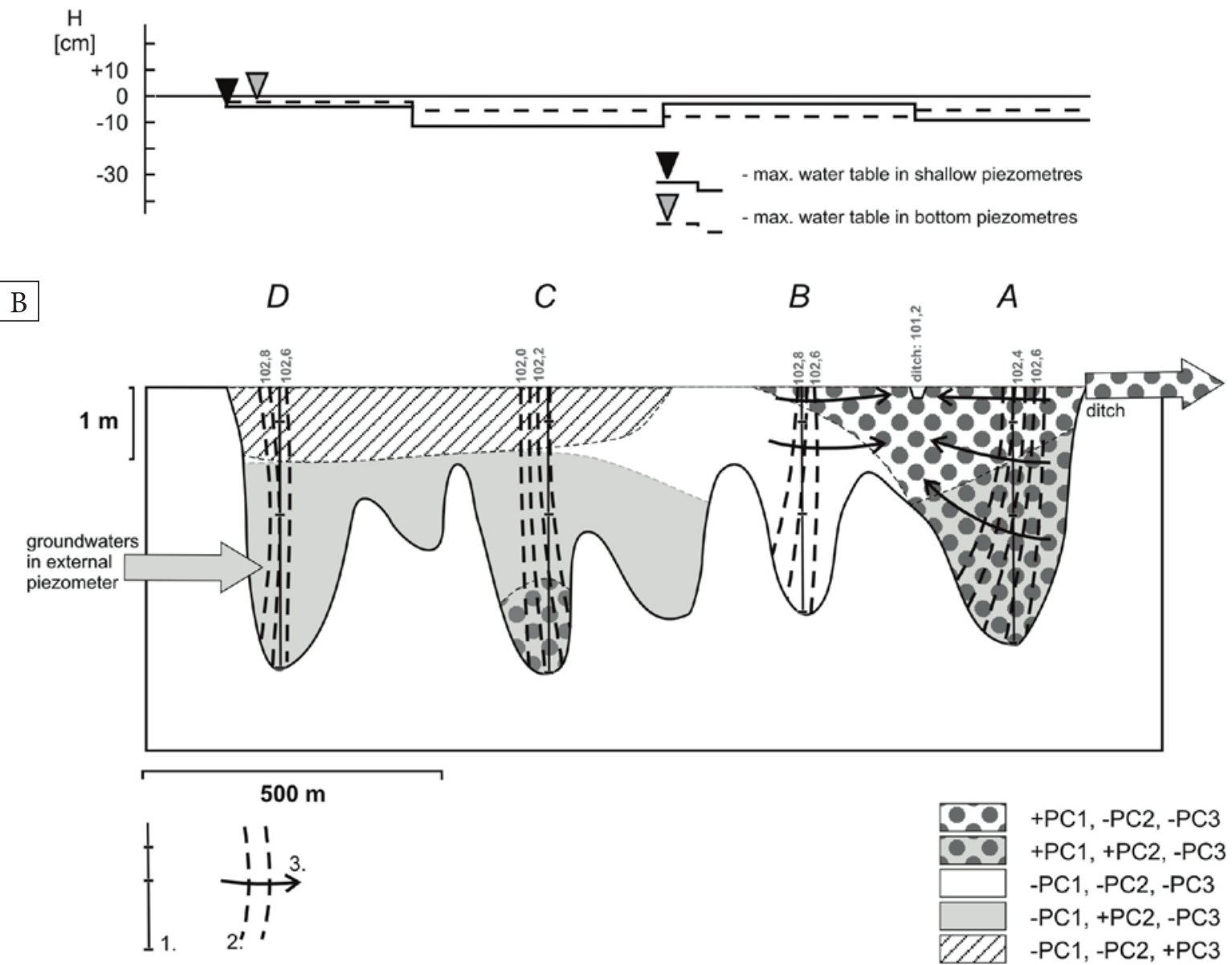

Fig. 2. Hydrochemical conditions of the Kopanicha (KA) peatland: A) average water levels in sampling sites; B) distribution of three principal components in the cross-section A-D; 1 - sampling sites in the peatland profile, 2 - equipotential lines, 3 -groundwater flow direction 
A

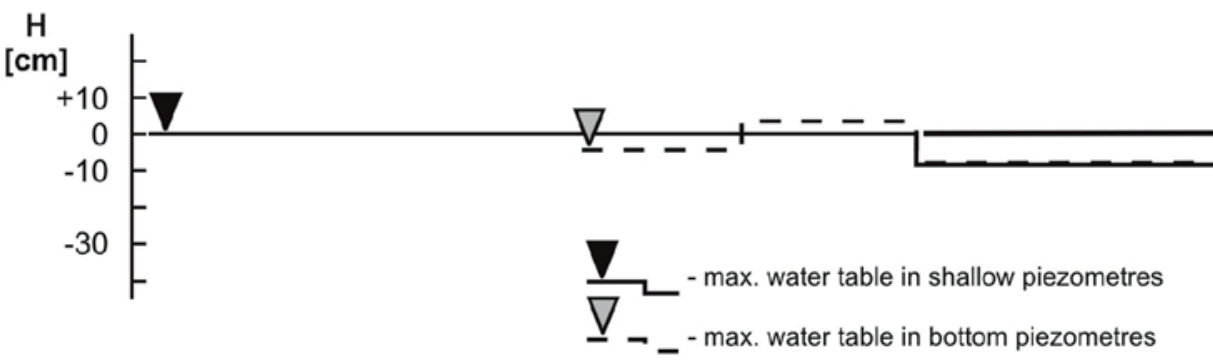

B

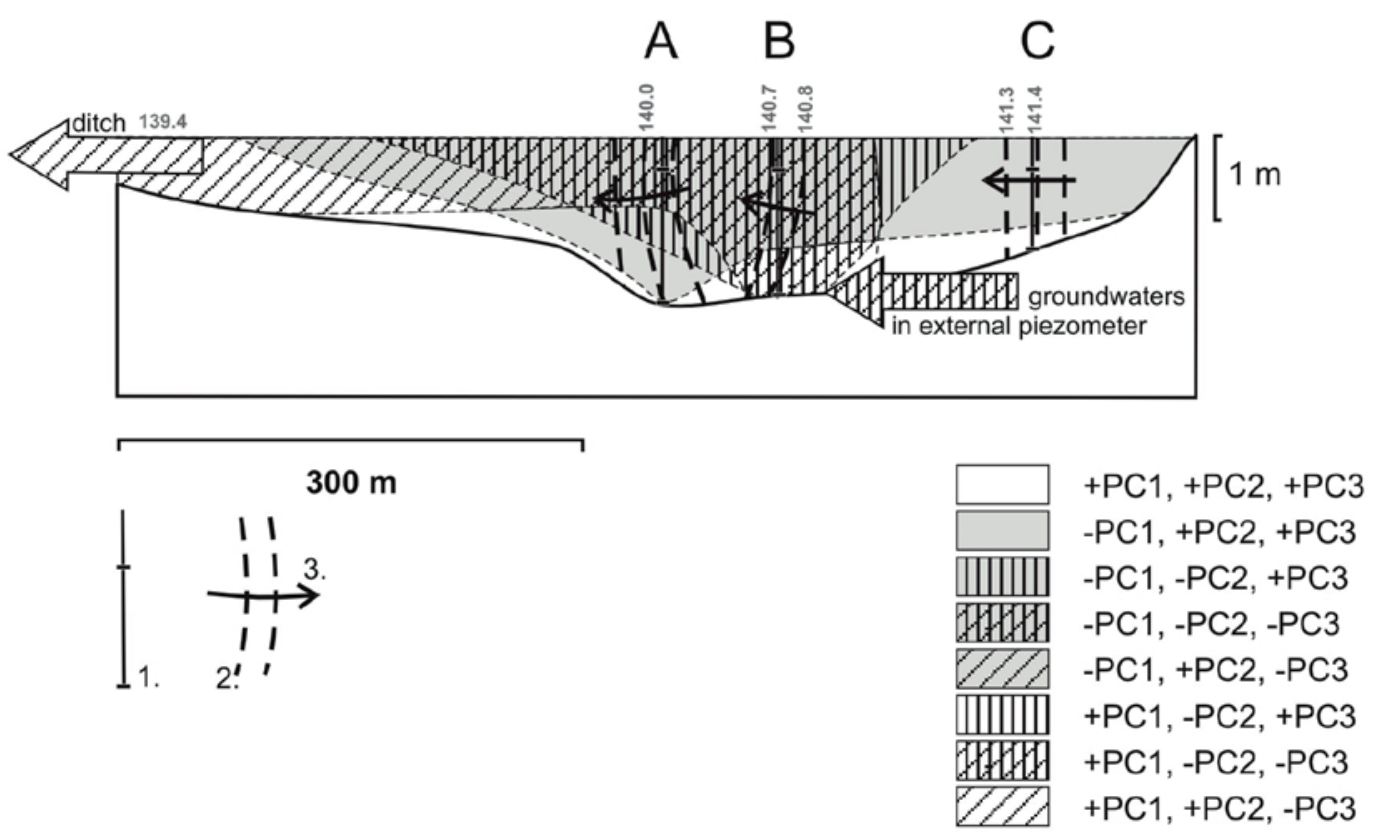

Fig. 3. Hydrochemical conditions of the Korzeń (KR) peatland: A) average water levels in polygones; B) distribution of the three principal components in cross-section A-C; 1 - sampling sites in the peatland profile, 2 - equipotential lines, 3 - direction of groundwater flow

This method of sampling peat waters from three depths was applied, among others, by Steinmann \& Shotyk (1997).

The external groundwaters were monitored with the use of single piezometer located in the outside the valley (Fig. 1). External piezometer of KR was screened in the depths interval $2.50-4.50 \mathrm{~m}$, and external piezometer of KA: $9.50-10.5 \mathrm{~m}$.

Waters outflowing from the peatlands were sampled in ditches, in KR, below the dyke enclosing the peatland and in $\mathrm{KA}$, above the place where the ditch stretched beyond the peatland (Fig.1).

Before water samples were collected from piezometers, the water table was recorded in connection with the level peatland surface. The results of such observations provided the basis for a limited analysis of the course of equipotential lines around the measured area. Next, water in the piezometers was exchanged twice. Water was pumped to the measurement chamber with no access to air, and water temperature, $\mathrm{pH}$, oxidation-reduction potential (Eh), electrolytic conductivity (EC), oxygen concentration and saturation of water with oxygen were measured. The measurements were conducted by means of Elmetron equipment: $\mathrm{CP}$ $315 \mathrm{~m}$, CO 315, CX 742, with relevant electrodes and sensors (made by Elsent, Poland).

Water samples for chemical analyses were collected in single PE bottles, filtered through a $0.45 \mathrm{~mm}$ pore size membrane filter (MCE), and preserved in $\mathrm{HNO}_{3}$, if necessary. The analysis of all the water samples (Ca, Mg, $\mathrm{Na}, \mathrm{K}, \mathrm{Fe}$ and $\mathrm{Mn}$ ) involved flame absorption spectrophotometry (Varian SectrAA 300). For $\mathrm{NH}_{4}, \mathrm{NO}_{2}, \mathrm{NO}_{3}, \mathrm{PO}_{4}$ and silica, this also required UV-VIS spectrophotometry (Marcel S.330). $\mathrm{SO}_{4}$ was determined by 
the gravimetric method (PN-C-04566-09), $\mathrm{Cl}$ by Mohr's method (PN-ISO 9297), $\mathrm{HCO}_{3}$, according to the PN-ISO 9963-1 method and colour of water, by the PN-ISO 7887 method. Total dissolved nitrogen (TDN) and phosphorus (TDP) were determined by means of Hach spectrophotometry with standards. DOC concentrations were carried out with a Shimadzu TOC 5050A Carbon Analyser.

Outflowing waters were taken from banks of the ditches and analysed by means of submerging electrodes and sensors, and then water was sampled from the water current. The study also involved measurements of water discharge by the float (KA) or volumetric method (KR).

Physical and chemical analyses and samplings were preceded by measurements of the water table level in piezometers. This demonstrated the piezometric pressures occurring in various parts of valley peatlands: uppermost, middle, and bottom parts, and between the peatland and the adjacent elevated area from which groundwaters are supplied.

Analyses of groundwaters, peat waters, and surface waters in KA were conducted at a total of 14 spots, and in KR in 8 spots. Sampling was performed once a season, from March 2010 to November 2011, as follows: KA - 18 March 2010, 8 July 2010, 7 October 2010, 19 January 2011, 5 April 2011, 7 July 2011, 3 November 2011, KR - 24 March 2010, 1 July 2010, 14 October 2010, 21 January 2011, 24 March 2011, 19 June 2011, 6 November 2011.

Geochemical conditions of free waters in the studied peatlands were identified by the $\mathrm{pH}$ of peat, determined in distilled water (Myślińska 1999).

Samples were collected from the nests in the depths of the location activity, with hydraulic parts of the installed piezometers.

\section{HYDROCHEMICAL INTERPRETATION OF DATA SETS}

The collected hydrochemical data were aggregated by the PCA method, providing the basis for the identification of the basic processes, determining the relevant information (Labus \& Siwek 2001). According to Mucina \& Polacik (1982), the method reveals the primary directions of hydrochemical variability of peatlands, which can be interpreted in terms of ecological gradients. Before the application of the PCA method, a series of hydrochemical data was verified in terms of the normality of the distribution, by means of the Shapiro-Wilk W test. Multimodal and skew systems were subjected to transformation, in accordance with Norcliffe (1986). Transformed calculations for PCA were mathematically modified values. Statistical calculations were performed with Statistica 7.1 software (Statsoft Inc. 2005). The collected hydrochemical data were obtained in separate matrices for each of the peatlands, and transformed to determine surrogate variables. These were selected as factors. The matrix was rotated by the varimax method, in order to maximise the variance in the columns. Factors important for the explanation of data variance were selected by the Cattella screening method (the scree method).

The verification of the similarity analysis by criteria specified in the PCA method involved the application of the model of water mix in a peatland, proposed by Reeve et al. (2001) and Siegel \& Glaser (2006):

$F_{\mathrm{GW}}=\left(C-C_{\mathrm{R}}\right) /\left(C_{\mathrm{GW}}-C_{\mathrm{R}}\right)$, where: $F_{\mathrm{GW}}$ - relative contribution of groundwaters in peatland waters, $C_{\mathrm{GW}}$ - concentration of the hydrochemical element in groundwaters, $C_{\mathrm{R}}$ - concentration of the hydrochemical element in precipitation waters, $C$ - concentration of the hydrochemical element in peatland waters.

The calculations involved the application of the chloride ion, because no flooding with river waters occured, and the concentrations of the ion in peat waters differed considerably from those in groundwaters.

The hydrogeochemical indicator method was applied to determine the complete interpretative possibility of direct comparison of the hydrochemical image of both of the analysed peatlands. Hydrogeochemical indices are used in hydrogeology to assess the state and hydrochemical transformation of groundwaters (Hounslow 1995, Razowska 1999). Among a high number of indicators, the following equivalence relations were selected: $r \mathrm{Na}^{+} /\left(r \mathrm{Na}^{+}+r \mathrm{Ca}^{2+}\right)$ and $r \mathrm{SO}_{4}^{2-} \cdot 100 / \mathrm{rCl}^{-}$, based on the results of the PCA, which distinguished some of the necessary hydrochemical elements.

The application of the hydrogeochemical indicator method in studies on peatlands was in 
accordance with Siegel \& Glaser (2006), who noted the importance of such methods in improving the methodology of ecological research on such subjects.

The necessity to inclue data on the amount and chemical composition of precipitation water in the analyses requires monitoring of the chemistry of atmospheric precipitation and contaminant depositions in the ground. The data set relevant in temporal and spatial terms was obtained by the courtesy of the Chief Inspector of Environmental Protection in Poland. The data concerned the period from 2009 to 2011 and is related to stations of the Institute of Meteorology and Water Management, located in the neighbourhood closest to the analysed peatlands, where the above-mentioned monitoring was conducted, i.e. Sulejów $\left(51^{\circ} 21^{\prime} 10^{\prime \prime} \mathrm{N}, 19^{\circ} 52^{\prime} 00^{\prime \prime} \mathrm{E}\right)$ and Warszawa-Okęcie $\left(52^{\circ} 10^{\prime} 03^{\prime \prime} \mathrm{N}, 20^{\circ} 58^{\prime} 29^{\prime \prime} \mathrm{E}\right)$.

\section{RESULTS}

\section{Hydrometeorological conditions}

The annual precipitation recorded in the stations of the Institute of Meteorology and Water Management in Sulejów in 2009, 2010 and 2011 amounted to 696, 710 and $563 \mathrm{~mm}$; in Warszawa-Okęcie to $659 \mathrm{~mm}, 797 \mathrm{~mm}$ and $609 \mathrm{~mm}$; and in Łódź-Lublinek to $660 \mathrm{~mm}, 754 \mathrm{~mm}$ and $471 \mathrm{~mm}$, respectively (GIOŚ 2012). According to the precipitation classification of Kaczorowska (1962), the study period was humid, and 2010 was extremely humid. Groundwaters responded by increasing supply. Their level successively increased from October 2009 to summer 2011 by $0.65 \mathrm{~m}$ in $\mathrm{KA}$ and by $0.36 \mathrm{~m}$ in KR. In the summer-autumn season, the groundwater level slightly decreased. The amplitude of groundwater levels in the observation period amounted to $0.65 \mathrm{~m}$ in the case of KA (from $9.0 \mathrm{~m}$ b.g.l. to $8.35 \mathrm{~m}$ b.g.l.) and $0.36 \mathrm{~m}$ in KR (from $3.25 \mathrm{~m}$ b.g.l. to $2.89 \mathrm{~m}$ b.g.l.). Changes in the external piezometers caused a response in waters from the bottom part of the peatlands. In $\mathrm{KA}$, in all of the four nests, and at depths of 3-4 $\mathrm{m}$, a slow increase in the water level occurred. Between the beginning and end of the measurement period, the water level increased by a maximum of $0.12 \mathrm{~m}$, i.e. five times less than on the adjacent plain. In $\mathrm{KR}$, the bottom piezometers responded in the same way as groundwaters in the adjacent raised terrace. The water level increased until April 2011, reaching $5 \mathrm{~cm}$ above the peatland surface in the middle sampling site (B), and then successively decreased. As such the amplitude did not exceed $0.25 \mathrm{~m}$, i.e. 1.5 times less than in groundwaters in the raised terrace.

The relative level of the average peat water tables in piezometer nests and the pattern of equipotential lines in the substratum were documented by the differentiation of the sampling sites in terms of hydrogeological gradients (Figs 2, 3).

Surface outflow, recorded in drainage ditches, was of a permanent character in $\mathrm{KA}$, and varied from $5 \mathrm{dm}^{3} \cdot \mathrm{s}^{-1}$ to $12 \mathrm{dm}^{3} \cdot \mathrm{s}^{-1}$. In KR, the outflow was periodical. In spring 2010, it did not exceed $2 \mathrm{dm}^{3} \cdot \mathrm{s}^{-1}$. In spring 2011 , it reached $3 \mathrm{dm}^{3} \cdot \mathrm{s}^{-1}$. It disappeared completely after the second half of June 2011.

\section{Hydrochemical conditions}

The $\mathrm{pH}$ of peat in the near-surface part in KR varied from 4.3 to 4.8 , and gradually decreased with depth. In the middle part of the profiles, it varied from 3.8 to 4.7, and at the bottom from 4.0 to 4.4. The opposite tendency was observed in KA, where on the surface, $\mathrm{pH}$ of peat varied from 4.0 to 5.2 , in the middle part from 4.8 to 5.6 , and at the bottom from 5.1 to 6.8 .

Concentration of major ions in waters which were collected in both peatlands is presented in Figure 4.

The PCA calculation results of hydrochemical data are presented in Table 2. In the data set representing $\mathrm{KA}$, three factors were selected by the factor screening method, jointly identifying $67.5 \%$ of variance (Tab. 2). The variability of the factor scores of particular surrogate variables is presented in Figure 2.

$\mathrm{PC} 1$ showed the strongest positive correlation with the major cations and EC. PC1 had positive values in the $\mathrm{A}$ and $\mathrm{C}$ sampling sites, whereas in the first of them, positive values included the whole profile, and in the second one, only the bottom (Fig. 2B). Groundwaters showed a negative value of $\mathrm{PCl}$, and the waters in the ditch, a positive one. In the near-surface layer of KA, PC1 variability corresponded with water table fluctuations in the bottom parts of peatland (Fig. 5A). 


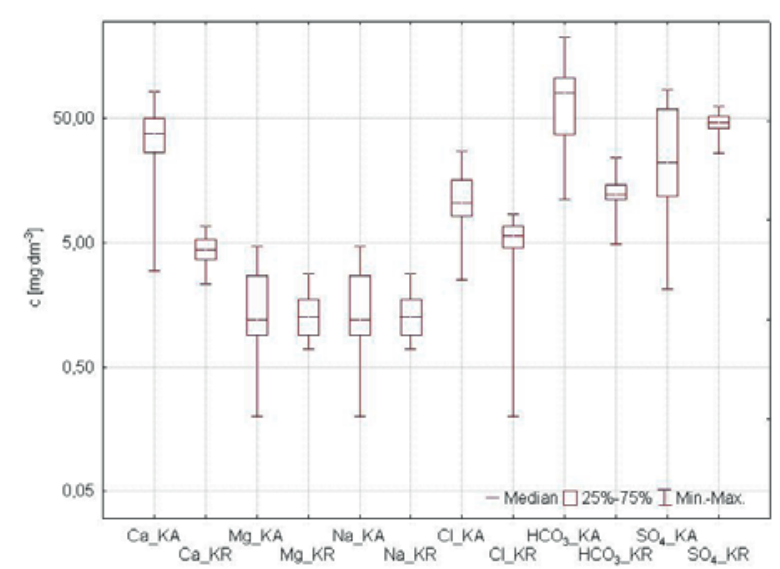

Fig. 4 . The ranges of major ion concentrations in waters of the investigated peatlands

The highest factor score in PC2 was representative of the water colour and concentration of ammonium ions. This surrogate variable constituted a criterion for distinguishing two horizontal parts in KA and distinguishing ditch waters and external groundwaters (Fig. 2B). PC2 values corresponded to changes in the water table, particularly in the middle part of the peat layer of KA (Fig. 5B).

TDN and $\mathrm{NO}_{2}{ }^{-}$anions were highly correlated in PC3. This surrogate variable showed positive values in a limited zone - the uppermost part of sites $\mathrm{C}$ and $\mathrm{D}$, morphologically the lowest part of KA (Fig. 2B). Groundwaters and ditch waters showed negative index values. Considerable responses of PC3 to water level fluctuations in piezometers were recorded in the upper parts of $\mathrm{KA}$ (Fig. 5C).

Four factors were selected from the hydrochemical data matrix of the KR in accordance with the factor screening method, identifying $74.5 \%$ of variance (Tab. 2). The highest component loadings in PC1 had positive values for Eh and ammonium ions and negative for TDP, orthophosphate ions, and oxygen demand. If $\mathrm{PC} 1>0$, the environment represented transitional to oxidising conditions, with a low concentration of dissolved phosphorus and organic substances, but increased concentrations of $\mathrm{NH}_{4}{ }^{+}$. When $\mathrm{PCl}<0$, concentrations of phosphorus and organic substances in water increased with a simultaneous decrease in the redox potential.
Table 2

Summary of principal components analysis of water chemistry

\begin{tabular}{|c|c|c|c|c|}
\hline \multirow{2}{*}{ Parameter } & \multicolumn{4}{|c|}{ Kopanicha (KA) } \\
\hline & \multicolumn{2}{|l|}{ PC1 } & PC2 & PC3 \\
\hline Cum. \% explained & \multicolumn{2}{|l|}{34.0} & 52.5 & 67.5 \\
\hline $\mathrm{Na}^{+}$ & \multicolumn{2}{|l|}{0.804} & 0.190 & -0.223 \\
\hline $\mathrm{K}^{+}$ & \multicolumn{2}{|l|}{0.326} & 0.306 & 0.086 \\
\hline $\mathrm{Ca}^{2+}$ & \multicolumn{2}{|l|}{0.839} & 0.207 & -0.054 \\
\hline $\mathrm{Mg}^{2+}$ & \multicolumn{2}{|l|}{0.933} & 0.022 & 0.070 \\
\hline $\mathrm{NH}_{4}^{+}$ & \multicolumn{2}{|l|}{-0.230} & -0.841 & -0.027 \\
\hline $\mathrm{Cl}^{-}$ & \multicolumn{2}{|l|}{0.689} & 0.225 & -0.206 \\
\hline $\mathrm{HCO}_{3}^{-}$ & 0.574 & & 0.391 & 0.000 \\
\hline $\mathrm{SO}_{4}{ }^{2-}$ & \multicolumn{2}{|l|}{0.693} & 0.129 & 0.134 \\
\hline $\mathrm{NO}_{2}^{-}$ & -0.001 & & -0.008 & 0.732 \\
\hline $\mathrm{PO}_{4}^{3-}$ & -0.334 & \multicolumn{2}{|c|}{0.167} & 0.354 \\
\hline TDN & -0.033 & & 332 & 0.802 \\
\hline TDP & -0.206 & & .071 & 0.056 \\
\hline Oxygen demand & 0.132 & & 318 & -0.695 \\
\hline Colour & -0.144 & & 880 & 0.087 \\
\hline EC & 0.868 & & 073 & -0.009 \\
\hline $\mathrm{pH}$ & 0.219 & & 688 & 0.003 \\
\hline Eh & 0.103 & & 092 & -0.197 \\
\hline & & Korze & í (KR) & \\
\hline Parameter & PC1 & PC2 & PC3 & PC4 \\
\hline Cum. \% explained & 28.2 & 48.3 & 64.0 & 74.5 \\
\hline $\mathrm{Na}^{+}$ & -0.124 & 0.843 & -0.117 & -0.205 \\
\hline $\mathrm{K}^{+}$ & 0.095 & 0.314 & 0.361 & -0.397 \\
\hline $\mathrm{Ca}^{2+}$ & -0.045 & 0.825 & 0.114 & -0.279 \\
\hline $\mathrm{Mg}^{2+}$ & -0.232 & -0.021 & 0.677 & -0.055 \\
\hline $\mathrm{NH}_{4}^{+}$ & 0.894 & 0.017 & -0.235 & 0.149 \\
\hline $\mathrm{Cl}^{-}$ & 0.151 & 0.061 & 0.887 & -0.043 \\
\hline $\mathrm{HCO}_{3}^{-}$ & 0.034 & 0.019 & -0.133 & -0.853 \\
\hline $\mathrm{SO}_{4}{ }^{2-}$ & -0.220 & -0.120 & 0.883 & 0.152 \\
\hline $\mathrm{NO}_{2}^{-}$ & -0.133 & 0.566 & -0.470 & -0.330 \\
\hline $\mathrm{PO}_{4}^{3-}$ & -0.744 & 0.329 & -0.176 & 0.197 \\
\hline $\mathrm{SiO}_{2}$ & -0.463 & -0.585 & 0.055 & 0.203 \\
\hline TDN & 0.234 & -0.099 & -0.138 & -0.191 \\
\hline TDP & -0.741 & 0.332 & -0.153 & 0.182 \\
\hline DOC & 0.026 & 0.603 & 0.008 & 0.384 \\
\hline Oxygen demand & -0.706 & -0.287 & 0.029 & 0.437 \\
\hline Colour of the water & 0.178 & 0.156 & 0.030 & -0.061 \\
\hline EC & -0.483 & -0.050 & 0.724 & 0.122 \\
\hline pH & 0.027 & 0.248 & 0.005 & -0.870 \\
\hline Eh & 0.897 & 0.017 & -0.235 & 0.149 \\
\hline
\end{tabular}


$\mathrm{A}$

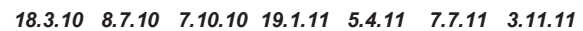

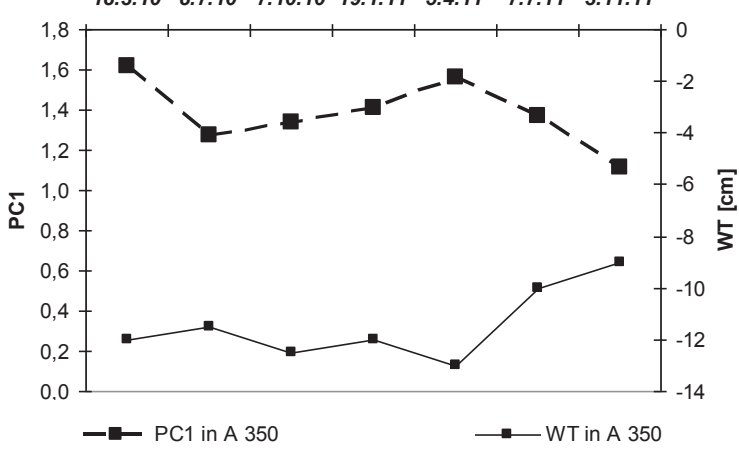

C

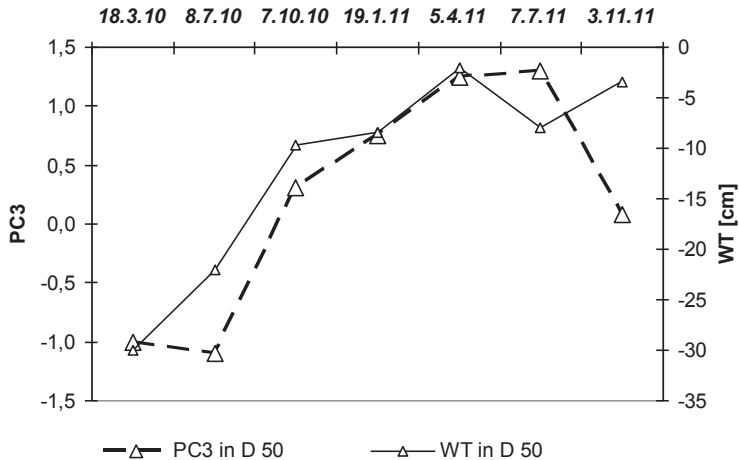

E

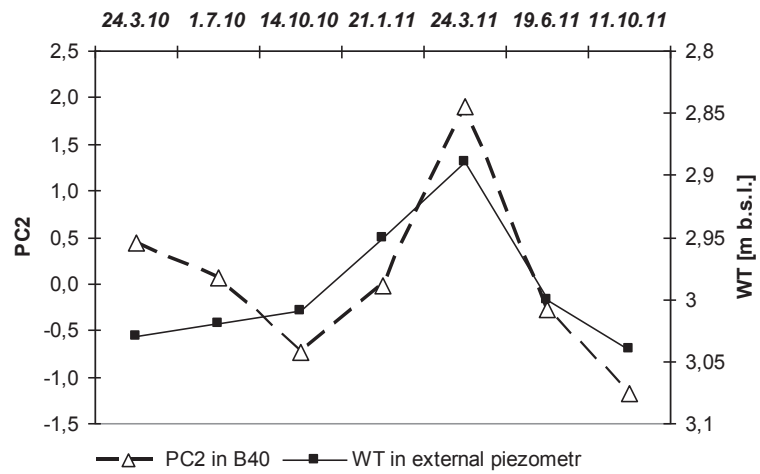

$\mathrm{B}$

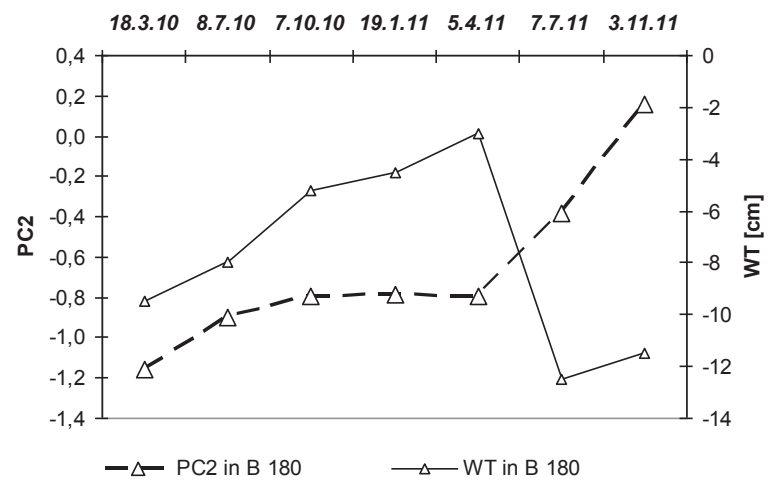

$\mathrm{D}$

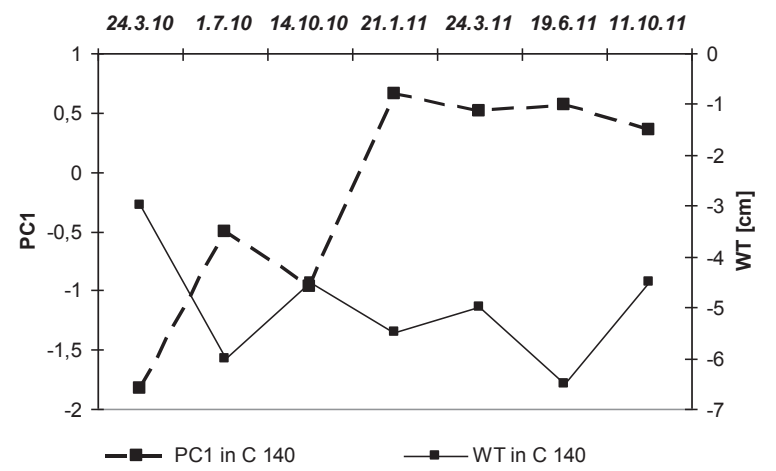

$\mathrm{F}$

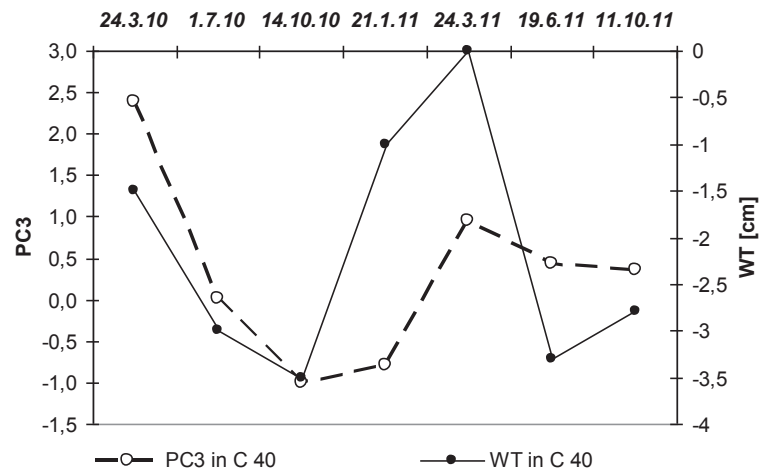

Fig. 5. Response of values of surrogate variables to water level fluctuations in the selected piezometers of studied sampling sites KA and KR; PC1, PC2, PC3 - principal component, WT - water table in piezometer

The factor scores of PC1, distributed in the KR profile along the line connecting sampling sites, divided the peatland into the upper part with negative values, and the lower part with positive ones (Fig. 3B). PC1 variability corresponded with the water table fluctuations in bottom parts of peatland (Fig. 5D).

The second surrogate variable was significantly positively correlated with calcium and sodium ions. PC2 showed negative values in groundwaters and in a limited zone in peatland -all of site $\mathrm{B}$ and the upper part of A (Fig. 3B). PC2 also corresponded with water table fluctuations in the mineral sediments adjacent to KR (Fig. 5E).

PC3 was composed of chlorides, sulphates, and EC. This surrogate variable had negative values in all of site $B$, the upper part of $A$ and in the ditch and groundwaters (Fig. 3B). PC3 variability corresponded with water table fluctuations in the upper part of peatland (Fig. 5F). 
The $F_{\mathrm{GW}}$ index was calculated for the chloride ion concentration base. In $\mathrm{KA}$, the values of this index varied between 1.05 and 3.50 (Fig. 6A). Generally, values showed mosaic configuration and a tendency to decrease from A to D sampling sites, reaching values close to one, typical of groundwaters. Values of the $F_{\mathrm{GW}}$ index for KR changed in the interval 0.64 to 1.65 (Fig. 6B). In this case, values close to one occurred in the whole of sampling site $B$ and in the ditch water.
The ratio $r \mathrm{Na}^{+} /\left(r \mathrm{Na}^{+}+r \mathrm{Ca}^{2+}\right)$ and the ratio $r \mathrm{SO}_{4}{ }^{2-} \cdot 100 / \mathrm{rCl}^{-}$values are represented in the diagram by a set of points delineated with a triangle for interpretative purposes (Fig. 7). Points representing KR are located in the top part of the triangle, and points representing KA in its bottom part. Atmospheric precipitation from the monitoring sites in Sulejów and Warszawa-Okęcie, represented by annual arithmetic means of each sampling year, is located near the bottom right apex of the triangle.

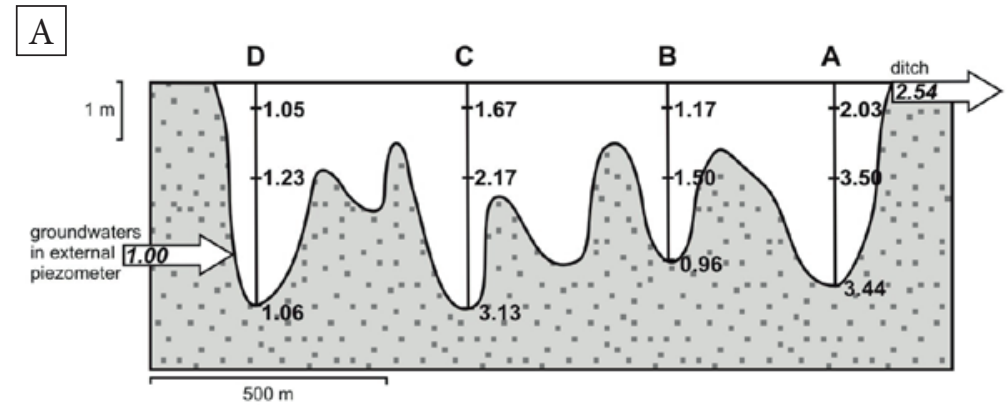

$\mathrm{B}$
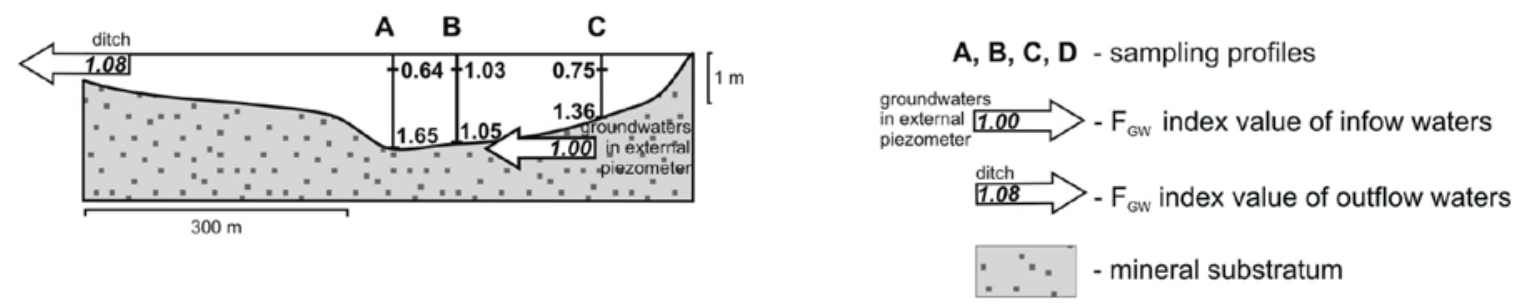

Fig. 6. Values of $F_{G W}$ index of sampling waters in the cross-section of Kopanicha (KA) (A) and Korzeń (KR) (B) peatlands

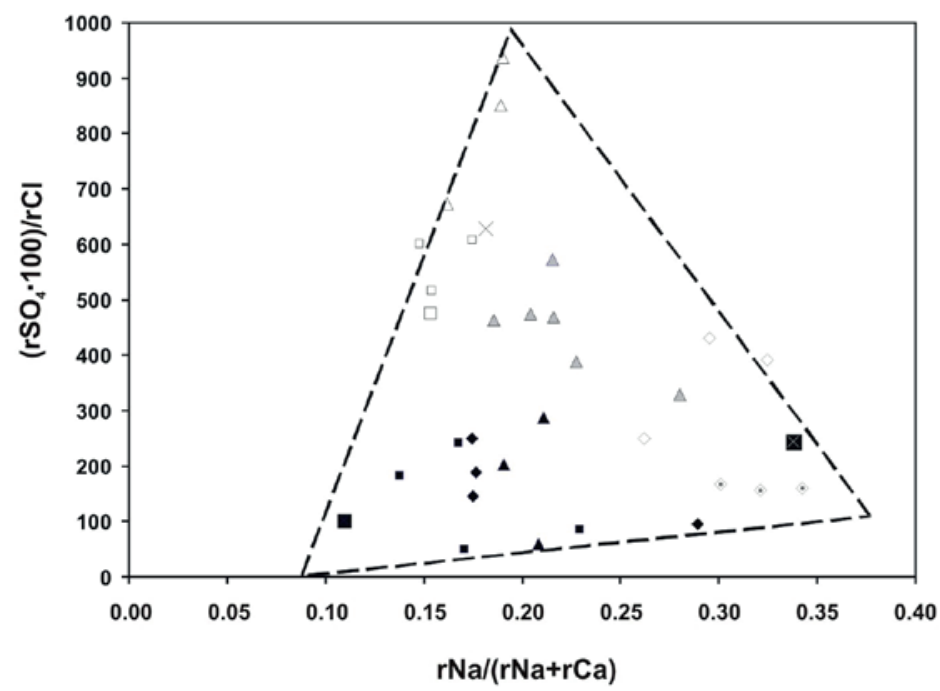
$1.2 .3 .4 .5-K A$ sampling sites: 1 - groundwaters in external piezometer, 2- bottom zone of peatland, 3- middle zone of peatland, 4- subsurface zone of peatland, 5- draining ditch
$\times \square \Delta$ - KR sampling sites: 1- groundwaters in external piezometer, 2- bottom zone of peatland, 3 - subsurface zone of peatland, 4- draining ditch
- KA sampling site $B$
- precipitation data from Sulejów (1.) and Warszawa-Okęcie (2.)

Fig. 7. Relationship between mean values of two hydrochemical ratios for sampling waters in Kopanicha (KA) and Korzeń (KR) peatlands 
The sulphate index in the case of KR presented high and variable values, accompanied by low and relatively permanent values of the sodium-calcium index.

In the case of KA, the sulphate index presented lower values with a narrower range than the sodium-calcium index, with the minimum value represented by water from the ditch, and the maximum, at the level relevant to precipitation, by groundwaters. In both peatlands, waters from near-surface piezometers showed a similar orientation, although points are shifted in the triangle: high variability of the sulphate index, at low variability of the sodium-calcium index. Such distributions of points have axes parallel to the left side of the triangle. In the case of KA, the spatial orientation changes towards an axis parallel to the base of the triangle with depth of water sampling. Waters from the bottom of KA have such an orientation. The variability of precipitation corresponds, to a certain degree, with the right side of the triangle.

\section{DISCUSSION}

The adopted temporal regime of the research limited the possibility of identifying seasonal water level fluctuations in piezometers. The measurements were performed during a very humid period, when restoration of water resources was recorded (from April 2011). The water table in the peatland, throughout the observation period and in all of the measurement sites, remained at a level no less than several $\mathrm{cm}$ below the peatland surface.

The composition of the surrogate variables distinguished in the PCA and the differentiation of the studied peatlands suggest the influence of two groups of environmental gradients. The first group includes hydrochemical elements showing how the peatland, represented by its waters, is affected by the supplied groundwaters - an external factor. The second group includes elements reflecting processes occurring within the peatlands themselves - an internal factor.

The "mineral" factors, representing the conditions of groundwater supply, include the major ions and EC (Blancher \& McNicol 1987, Reeve et al. 1996). In the cross-sections of the studied peatlands, the factors document phenomena which occur vertically between the bedrock and surface, but only in certain parts of KA and KR (Figs 2, 3). In the case of KA, the highest contribution of all is made by "mineral factors" in explaining the variance. In KR, their contribution is lower, and the mentioned hydrochemical elements are included in further surrogate variables. The division of the major ions between PC2 and PC3 suggests their variability in peat waters is determined by various processes. Chlorides and sulphates provide hydrochemical evidence of the groundwater supply from the catchment covered with a coniferous forest in a relatively poor habitat, namely a dry and fresh one. Such a division can also be a representation of wet atmospheric depositions (Blancher \& McNicol 1987), or alternate processes of release and retention of sulphur, depending on the water level in the peatland (Bayley et al. 1986, McLaughlin \& Webster 2010). The graphic image of the relation of sulphates to chlorides described by the sulphate index leads to two basic processes: release of sulphates in the near-surface zone of the studied peatlands, and their supply of groundwaters (Fig. 6). The course of the processes in peatlands, with the dominance of the first process over the second one, determines the location of points from KR along the axis parallel to the left side of the triangle, and in the case of $\mathrm{KA}$, where groundwater supply is dominant, the distribution of points shows a different orientation.

The second distinguished pair of ions, $\mathrm{Na}^{+}$ and $\mathrm{Ca}^{2+}$, is very frequently interpreted in PCA of peat waters, together with other macro ions, as evidence of groundwater supply to peatlands (Blancher \& McNicol 1987, Kizuka et al. 2008, Stelmaszczyk et al. 2009). Traces of penetration of KR by groundwaters are found in the depth distribution of $\mathrm{PC} 2$ values. The entire profile of site $\mathrm{B}$ clearly corresponds with groundwaters (Fig. 3B), also, in terms of seasonal variability (Fig. 5E). It is the fragment of KR as well where the table of water sampled from the bottom stabilizes in the piezometer above the peatland surface (Fig. 3A). This suggests groundwater ascent.

The calcium ion deficit in the supplied groundwaters in relation to peatwaters and its concentration in waters drained by the ditch suggest a $\mathrm{Ca}^{2+}$ release. This may result from the transformation of sulphur compounds (Bayley et al. 1986) or their 
displacement by hydrogen cations, which lead to a successive decrease in the reaction of peat (Urban et al. 1995). The tendency of changes in the reaction of peat in KR to depth suggests that the process proceeds from the bottom of the peatland, where groundwaters are supplied, with a mean reaction of 4.57 , i.e. lower than waters from the near-surface zone. Therefore, in KR, calcium concentrations clearly identify the character of the environment of groundwaters as different from that of peat waters (Fig. 5E).

In conditions of documented decalcination of the uppermost layers of Quaternary formations in the periglacial area, as a result of their penetration by aggressive meteoric waters, the content of calcium in groundwaters differentiates the shallower aquifer overlying clay from the deeper interclay and sub-clay ones. This phenomenon causes the hydrochemical differentiation of peat waters in KA. The distribution of $\mathrm{PC1}$ for the KA profile (Fig. 2B), and results of calculations of $F_{\mathrm{G}}$ (Fig. 5A), suggest the peatland's supply comes from various aquifers. It is also suggested by varied responses of $\mathrm{PC} 1$ to changes in piezometric pressures during the study term (Fig. 5A). The range of groundwaters covers part of the study sites, particularly in sampling sites B and D (Fig. 3B). Confined groundwaters particularly influence site $A$ and the bottom part of site C. Waters drained by the ditch are related to confined groundwaters to a higher degree than to unconfined groundwaters. The possibility of supplying peatlands located in the middle section of the Rawka River valley from two aquifers was suggested by Żurek (1990) (Tab. 1). This is also in accordance with the local hydrogeological conditions determined from profiles of wells located between Skierniewice and KA (CHDB 2013).

The relation of sodium and calcium ions in the peat waters of KA and KR, reflected in the applied hydrochemical index and presented in the diagram (Fig. 7), is interpreted as a result of groundwater supply in the KA peatland and cation retention in the KR peatland.

The remaining factors determined in the PCA, i.e. the second and third for $\mathrm{KA}$, and the first one for $\mathrm{KR}$, are correlated with processes occurring within peatlands and distinguish horizontal zones in the cross-section of the peatlands (Figs 2,3).
The hydrochemical element worthy of special consideration is ammonium cation, an important element of the PC2 for KA and PC1 for KR. Co-determining surrogate variables showed that ammonium ion in the first case is associated with water colour, and in the second case, with redox potential, phosphates, and TDP (Tab. 2). A very similar composition of the surrogate variable was obtained by Blancher and Nicol (1987). In KA and $\mathrm{KR}$, negative values of the "ammonium" factors distinguished waters sampled from the surface peat layer and waters in the peat, but not in surface water bodies (Figs 2, 3). In KA, the PC2 variable permits us to distinguish the zone of active decomposition of organic matter in the top part of the peatland and in the entire profile of site B. In $\mathrm{KR}$, the ammonium cation is accompanied by a redox potential which, as suggested by the construction of PC1, contributes to the differentiation of KR in terms of the availability of phosphorus, which prefers reduction conditions. The most abundant area in this regard is the uppermost layer of KR, particularly in sampling sites located in the well hydrated central and northern parts.

The PC3 distinguished from the hydrochemical data set KA strongly corresponds with TDN and $\mathrm{NO}_{2}^{-}$(Tab. 2). The distribution of PC3 values suggests the existence of a near-surface zone rich in nitrogen in the northern fragment of KA, which is also affected by the degree of water accumulation in the near-surface peatland layers. This factor can reflect the spatial trophic gradient in a fen. Its presence is confirmed by the analyses of diatom assemblages, documenting the eutrophy of the northern fragment of KA and the mesotrophy of the southern fragment (Ziułkiewicz \& Żelazna-Wieczorek 2012).

Analysis of the similarity of waters drained by ditches to peat waters and groundwaters, performed on the basis of accordance of factor scores of distinguished surrogate variables, suggests that the studied peatlands differ from each other in terms of the relation between the supplied groundwaters and waters drained by the ditch. In $\mathrm{KR}$, waters of both environments definitely belong to the same group. In KA, drainage by the ditch reaches the shallowest zone of the peatland, and with the exception of sampling site $B$, it does not approach its deeper parts. From the perspective of 
particular factors, it seems that this synthetic assessment is largely coherent with the distribution of PC2 in the profile of KA. The consideration of the remaining surrogate variables provides evidence of the effect of groundwaters on the studied peatlands. In KA, two zones are distinguishable: one affected by groundwaters, sampled by means of a piezometer outside the peatland, and the second one affected by confined groundwaters. Water supply from different aquifers is determined by local geological conditions. In the profile of site $\mathrm{C}$, the deepest in $\mathrm{KA}$, the analysis of the distribution of the major ions $\left(\mathrm{PCl}\right.$ and index $F_{\mathrm{G}}$ ) reveals a tripartite hydrochemical character. Confined groundwaters occur at the bottom, groundwaters in the middle part, and peat waters at the surface, largely affected by transformations of organic formations, with a low degree of decomposition. In $\mathrm{KA}$, groundwaters generally predominate in the middle and bottom parts of the peatland. The uppermost part is dominated by peat waters, additionally differentiated in terms of the degree of eutrophication.

In the case of $\mathrm{KR}$, a zone can be distinguished located outside the range of the effect of groundwaters. Consequently, the remaining part has a transit character. Mixing of groundwaters with peat waters occurs in the near-surface part of sites $\mathrm{A}$ and $\mathrm{B}$. This is confirmed by factor scores of PC2 and PC3 (Fig. 3), and suggests the existence of a separate group of research points with an intermediate position between the 'transit' group and the group with no trace of groundwater effects. The results of calculations of the $F_{\mathrm{G}}$ index (Fig. 5B) suggest the uppermost part of site $\mathrm{B}$ is related to the transit to a higher degree than site A. The difference between them results from the local pressure of groundwaters, which reaches the surface of KR in site B (Fig. 3A).

The scale and character of the hydrochemical relation between groundwaters and waters drained from the peatlands by the ditch is also reflected in the values of hydrochemical indicators (Fig. 7), permitting the comparison of the peatlands. The distance between groundwaters and waters from the ditch suggests that this similarity occurs in KR. In KA, the types of water represent different environments. The dispersion of points along the axis of the diagram determines the character of the similarity: in KA, because of sulphates and chlorides, in KR, because of sodium and calcium.

The hydrochemical image of the surface outflow showing precipitation and groundwaters indicates the group of factors which determine the conditions occurring in the peatland. The interpretation is facilitated by comparing the values of two hydrochemical indicators. Groundwater supply from outside the range of decalcination is typical of points located in the left bottom apex of the triangle. Groundwater supply from decalcinated rock formations, strongly related to precipitation waters, corresponds with the right bottom apex of the triangle. The bottom side corresponds to fens supplied with groundwaters and confined groundwaters. The right side constitutes the axis in relation to which the scale of transformation of groundwaters resulting from processes occurring within the peatland, distinguished by a certain existing autonomy, can be determined. Therefore, the top apex represents the autonomous environment. In the case of valley peatlands, the transitional character is always preceded by the groundwater supply phase. As a result, a high amount of alkaline cations can accumulate in the peat. Consequently, later supply of atmospheric precipitation poor in cations is masked by their release from the peat, recorded in the outflow. This is evidenced by a group of points representing sampling site B in KA (Fig. 7). It connects the 'precipitation' apex with the part of the diagram, where representatives of the transitional bog $-\mathrm{KR}$ - are located. The points, however, are not distributed along the right side of the diagram, although in terms of the plant assemblage, the site represents an enclave of the raised bog within KA, overgrown by a marshy coniferous forest. High pressure of groundwaters, and particularly confined groundwaters, because of chloride concentrations, does not permit high values of the sulphate index, therefore filling the right top part of the triangle with an empirical representation.

\section{CONCLUSIONS}

The analysis of the hydrochemistry of two valley peatlands, Kopanicha (KA) and Korzeń (KR), permitted us to distinguish two groups of 
hydrochemical elements responsible for their character and related to the primary ecohydrological processes occurring in peatlands. The first one includes elements related to groundwater supply. The second group identifies products of transformations within weakly developed organic sediments. The order of participation of surrogate variables representing such processes in the explanation of the variance of the hydrochemical data set provides a basis for the determination of their importance. The "mineral" factor is dominant in $\mathrm{KA}$, whereas in KR, "mineral" and "organic" factors are of equal significance.

In the vertical profile of the peatlands, two distinct zones can be distinguished: the near-surface zone that is the subject of strong internal processes in the peatland, and the deep zone, dominated by the effect of external factors.

The near-surface zone can be discerned by the availability of biogenic elements: nitrogen (TDN, $\mathrm{NO}_{2}^{-}$) in $\mathrm{KA}$ and phosphorus $\left(\mathrm{PO}_{4}^{3-}, \mathrm{TDP}\right)$ in $\mathrm{KR}$. Deep zones are described in terms of the range of effects of different groundwaters. In KA, unconfined groundwater feeds the central and northern parts of the peatland, whereas confined groundwaters flow into the southern part. In KR, unconfined groundwaters flow into the central part of the peatland. These effects appear in the near-surface zone and the ditch waters too. Confined groundwaters deliver the base cations, whereas unconfined, slighty mineralized groundwaters, from decalcified shallow sediments, can lead to the acidification of those parts of peatland which are washed. Such impact by groundwaters is legible in the $\mathrm{pH}$ of peat in both the peatlands analysed.

Hydrochemical zoning of peatland is the base for identifying the principal origin of water outflow by ditches. Limiting the number of hydrochemical elements distinguished in the PCA to pairs of the major ions simplifies the assessment. Values of hydrochemical indices calculated for outflow waters were compared with essential elements of feeding structure. Low values of the sulphate and sodium-calcium indices show groundwater supply. Low values of the sulphate index and high values of the sodium-calcium index are indicative of precipitation of the water supply. High values of the sulphate index and increased sodium-calcium index are indicators of water transformation in the peat. In terms of hydrochemical properties, outflow waters in Kopnicha (KA) are suitable for groundwaters; whereas in Korzeń (KR), outflow represents waters transformed in peatland in contact with organic sediments.

The diagram of hydrochemical indices can be used for the simplified hydrochemical interpretation of surface outflow and the identification of the dominant type of water relations in the peatland.

This investigations was supported by the Polish State Committee for Scientific Research under project no. N 306276735.

\section{REFERENCES}

Banaś K. \& Gos K., 2004. Effect of peat-bog reclamation on the physico-chemical characteristics of the ground water in peat. Polish Journal of Ecology, 52, 1, 69-74.

Bayley S.E., Behr R.S. \& Kelly C.A., 1986. Retention and release of a $S$ from a freshwater wetland. Water, Air and Soil Pollution, 31, 101-114.

Blancher P.J. \& McNicol D.K., 1987. Peatland water chemistry in central Ontario in relation to acid deposition. Water, Air and Soil Pollution, 35, 217-232.

Brzeziński M., 1998. Objaśnienia do Szczegółowej mapy geologicznej Polski 1:50 000. Arkusz Bolimów (556). Wydawnictwa Geologiczne, Warszawa.

CHDB (Centralna Baza Danych Hydrogeologicznych, System Przetwarzania Danych Państwowej Służby Hydrogeologicznej), 2013. Państwowy Instytut Geologiczny - Państwowy Instytut Badawczy, Warszawa, [on-line:] http://spdpsh.pgi.gov.pl/PSHv7/ [access: 20 April 2013].

Dembek W. \& Oświt J., 1992. Rozpoznawanie warunków hydrologicznego zasilania siedlisk mokradłowych. [in:] Jankowska-Huflejt H. (red.), Hydrogeniczne siedliska wilgotnościowe, Biblioteczka Wiadomości IMUZ 79, Wydawnictwo Instytutu Technologiczno-Przyrodniczego, 15-38.

Falkowski T. \& Złociszewska-Niedziałek H., 2008. Rozpoznanie budowy geologicznej dla hydrogeologicznego modelu zasilania torfowiska rezerwatu Czerwone Bagno. Biuletyn Państwowego Instytutu Geologicznego, 431, 35-40.

Forysiak J., Ziułkiewicz M., Kopeć D. \& Żelazna-Wieczorek J., 2011. Warunki przyrodnicze torfowiska Korzeń. [in:] Torfowiska dorzecza Widawki: wybrane problemy i przykłady. Warsztaty naukowe „Torfowiska w krajobrazie przeksztatconym”, 1-3 czerwca 2011 r.: przewodnik sesji terenowej, Wydawnictwo Instytutu Archeologii Uniwersytetu Łódzkiego, Łódź, 61-73.

Forysiak J., 2012. Zapis zmian środowiska przyrodniczego późnego vistulianu i holocenu w osadach torfowisk regionu łódzkiego. Acta Geographica Lodziensia 99, Łódzkie Towarzystwo Naukowe, Łódź.

Forysiak J., Kucharski L. \& Ziułkiewicz M., 2012. Peatlands in semi-natural landscape - their transformation and the possibility of protection. Bogucki Wydawnictwo Naukowe, Poznań 
GIOŚ, 2012. Zestawienie wyników badania składu chemicznego opadów atmosferycznych na posterunkach monitoringowych w Sulejowie i Warszawie-Okęciu w latach 2009-2011 [Sheet of chemical composition records from monitoring stations Sulejów and Warsaw-Okęcie in 2009-2011].

Hounslow A.W., 1995. Water quality data. Analysis and interpretation. Lewis Publishers, New York.

Ilnicki P., 2002. Hydrologia torfowisk. [in:] Ilnicki P. (red.), Torfowiska i torf, Wyd. Akademii Rolniczej im. Augusta Cieszkowskiego, Poznań, 159-172.

Kaczorowska Z., 1962. Opady w Polsce w przekroju wieloletnim: tendencje, okresowość oraz prawdopodobieństwo występowania niedoboru i nadmiaru opadów. Prace Geograficzne - Polska Akademia Nauk. Instytut Geografii 33, Wydawnictwa Geologiczne, Warszawa.

Kizuka T., Yamada H., Yazawa M. \& Hoi-Hoon Ch., 2008. Effects of agricultural land use on water chemistry of mire pools in the Ishikari Peatland, Northern Japan. Landscape and Ecological Engineering, 4, 1, 27-37.

Kobojek E., 2009. Naturalne uwarunkowania różnych reakcji rzek nizinnych na antropopresję na przykładzie środkowej Bzury i jej dopływów. Rozprawy Habilitacyjne Uniwersytetu Łódzkiego, Wyd. Uniwersytetu Łódzkiego, Łódź.

Kruk M., 2000. Biogeochemical functioning of hydrologically modified peatland and its effect in eutrophication of freshwaters. Polish Journal of Ecology, 48, 103-161.

Kruk M. \& Podbielska K., 2005. Trace metal fluxes in a sphagnum peatland - humic lake system as a consequence of drainage. Water, Air and Soli Pollution, 168, 213-233.

Krzemiński T. \& Bezkowska G., 1987. Objaśnienia do Szczegółowej mapy geologicznej Polski 1:50 000. Arkusz Widawa (698). Wydawnictwa Geologiczne, Warszawa.

Labus K. \& Siwek P., 2001. Wspomaganie interpretacji hydrochemicznych metodami analizy czynnikowej. [in:] Bocheńska T. \& Staśko S. (red.), Współczesne problemy hydrogeologii. 10, t. 2, "Sudety", Wrocław, 379-383.

Macioszczyk A., 1988. Chemizm wód podziemnych dolin rzecznych oraz główne czynniki kształtujące go. [in:] Kiciński T., Łoś M. \& Mioduszewski W. (red.), Zasilanie dolin rzecznych wodami gruntowymi, Zeszyty Problemowe Postępów Nauk Rolniczych 347, Państwowe Wydawnictwo Naukowe, Warszawa, 205-220.

McLaughlin J.W. \& Webster K.L., 2010. Alkalinity and acidity cycling and fluxes in an intermediate fen peatland in northern Ontario. Biogeochemistry, 99, 143-155.

Mitchell C.P.J. \& Branfireun B.A., 2005. Hydrogeomorphic Controls on Reduction-Oxidation Conditions across Boreal Upland-Peatland Interfaces. Ecosystems, 8, 731-747.

Mucina L. \& Polacik S., 1982. Principal components analysis and trend surface analysis of a small-scale pattern in a transition mire. Vegetatio, 48, 165-173.

Myślińska E., 1999. Parametry fizyczne torfów i ocena metod ich oznaczania. Przeglad Geologiczny, 7, 676-682.

Norcliffe G.B., 1986. Statystyka dla geografów: wprowadzenie. Państwowe Wydawnictwo Naukowe, Warszawa.

PN-ISO 7887:2002, Jakość wody - Badanie i oznaczanie barwy.

PN-ISO 9280:2002, Jakość wody-Oznaczanie siarczanów(VI) - Metoda grawimetryczna z chlorkiem baru.
PN-ISO 9297:1994, Jakość wody - Oznaczanie chlorków Metoda miareczkowania azotanem srebra $w$ obecności chromianu jako wskaźnika (metoda Mohra).

PN-ISO 9963-1:2001, Jakość wody - Oznaczanie zasadowości - Część 1: Oznaczanie zasadowości ogólnej i zasadowości wobec fenoloftaleiny.

Razowska L., 1999. Wskaźniki hydrochemiczne - mało przydatne czy niedoceniane. [in:] Krajewski S. \& Sadurski A. (red.), Wspótczesne problemy hydrogeologii. T. 9, Hydrogeologia na przełomie wieków, Warszawa-Kielce 15-17 września 1999, Państwowy Instytut Geologiczny, Warszawa, 307-313.

Reeve A.S., Siegel D.I. \& Glaser P.H., 1996. Geochemical controls on peatland pore water from the Hudson Bay Lowland: a multivariate statistical approach. Journal of Hydrology, 181, 285-304.

Reeve A.S., Siegel D.I. \& Glaser P.H., 2001. Simulating dispersive mixing in large peatlands. Journal of Hydrology, $242,103-114$.

Siegel D.I. \& Glaser P.H., 2006. The Hydrology of Peatland. [in:] Wieder R.K. \& Vitt D.H. (eds), Boreal Peatland Ecosystems, Ecological Studies 188, Springer Science \& Business Media, 289-311.

Skąpski K., Kruk L. \& Garecki J., 2000. Mapa hydrogeologiczna Polski w skali 1:50000. Arkusz Widawa (698). Państwowy Instytut Geologiczny, Warszawa.

Steinmann Ph. \& Shotyk W., 1997. Chemical composition, $\mathrm{pH}$, and redox state of sulfur and iron in complete vertical porewater profiles from two Sphagnum peat bogs, Jura Mountains, Switzerland. Geochimica et Cosmochimica Acta, 61, 6, 1143-1163.

Stelmaszczyk M., Chormański J., Grygoruk M., Kardel I., Okruszko T. \& Bartoszul H., 2009. Groundwater chemistry variation in wetland vegetation habitats of the „Red Bog Strict Protected Area". [in:] Łachacz A. (ed.), Wetlands: their functions and protection. Monograph, University of Warmia and Mazury, Faculty of Environmental Management and Agriculture, Olsztyn, 157-172.

StatSoft Inc., 2005. STATISTICA v. 7.1, ed. 0205a-P.

Tahvanainen T. \& Tuomaala T., 2003. The reliability of mire water $\mathrm{pH}$ measurements - a standard sampling protocol and implications to ecological theory. Wetlands, 23, 4, 701-708

Urban N.R., Verry E.S. \& Eisenreich S.J., 1995. Retention and mobility of cations in a small peatland: trends and mechanisms. Water, Air and Soil Pollution, 79, 201-224.

Wieder R.K. \& Lang G.E., 1986. Fe, Al, Mn and S Chemistry od Sphagnum Peat in Four PeatlandsWith Different Metal and Sulphur Input. Water, Air and Soil Pollution, 29, 309-320.

Ziułkiewicz M. \& Żelazna-Wieczorek J., 2012. Current ecological status of selected transitional peatlands in Central Poland in relation to hydrochemical conditions. [in:] Forysiak J., Kucharski L. \& Ziułkiewicz M. (eds), Peatlands in semi-natural landscape: their transformation and the possibility of protection, Bogucki Wydawnictwo Naukowe, Poznań, 59-72.

Żurek S., 1990. Związek procesu zatorfienia z elementami środowiska przyrodniczego wschodniej Polski. Roczniki Nauk Rolniczych, Seria D, Monografie 220, Państwowe Wydawnictwo Naukowe, Warszawa. 